\title{
Food Deprivation Limits Insulin Secretory Capacity in Postpubertal Rats
}

\author{
PATRICIA VUGUIN, XIAOHUI MA, XIOMAN YANG, MANJU SURANA, BING LIU, AND \\ NIR BARZILAI
}

\begin{abstract}
Department of Medicine, Divisions of Endocrinology and Geriatrics, Diabetes Research and Training Center [X.M., X.Y., M.S., B.L., N.B.], and Department of Pediatric Endocrinology [P.V.], Albert Einstein College of Medicine, Children's Hospital at Montefiore Medical Center, Bronx, New York 10461, U.S.A.;
\end{abstract}

e-mail:vuguin@aecom.yu.edu

\begin{abstract}
Because prenatal and perinatal undernutrition are associated with type 2 diabetes later in life, we posed the question whether nutrient deprivation during puberty would also result in a decreased ability to secrete insulin. Chronically catheterized, unstressed Sprague Dawley rats, fed ad libitum, were studied before puberty (Pre, $n=14$ ) and after puberty (Post, $n=8$ ). Moderately caloric-restricted rats (fed $70 \%$ of the control diet, $n=9$ ), were studied after puberty. Insulin secretion was assessed using a hyperglycemic clamp at a glucose concentration of $300 \mathrm{mg} / \mathrm{dL}$, or with a primed continuous infusion of intralipid (plasma FFA levels $\sim 1.5 \mathrm{mM}$ ) at a plasma glucose concentration of 200 $\mathrm{mg} / \mathrm{dL}$. Stimulated insulin levels increased in Post rats by $3-$ to 4-fold compared with Pre rats (from $4.6 \pm 0.4 \mathrm{ng} / \mathrm{mL}$ Pre to 12.8 $\pm 0.7 \mathrm{ng} / \mathrm{mL}$ Post, and from $4.5 \pm 0.4 \mathrm{ng} / \mathrm{mL}$ Pre to $15.8 \pm 0.7$ $\mathrm{ng} / \mathrm{mL}$ Post, respectively, $p<0.001$, at a glucose concentration of $300 \mathrm{mg} / \mathrm{dL}$, and $200 \mathrm{mg} / \mathrm{dL}$ with intralipid). Caloric restriction prevented any rise in insulin secretion $(3.8 \pm 0.5$ and $4.6 \pm 0.5$ $\mathrm{ng} / \mathrm{mL}$ in the caloric-restricted rats at glucose concentrations of $300 \mathrm{mg} / \mathrm{dL}$ and $200 \mathrm{mg} / \mathrm{dL}$ with intralipid, respectively). A semiquantitative reverse-transcriptase PCR procedure was used
\end{abstract}

\section{ABSTRACT}

to assess basal and stimulated insulin mRNA levels. Caloric restriction did not compensate by enhancing insulin mRNA levels in response to glucose stimulation. Moderate food deprivation during puberty reduced the capacity of the pancreas to secrete insulin in response to different nutrient stimuli. We hypothesize that puberty has an important role in $\beta$-cell maturation and any major nutrient modification may have deleterious consequences later in life. (Pediatr Res 49: 468-473, 2001)
AL, ad libitum
Pre, before puberty
Post, after puberty
$\mathbf{C R}$, caloric restricted
BW, body weight
LBM, lean body mass
FM, fat mass
GIR, glucose infusion rate
AUC, area under the curve
S-D rats, Sprague Dawley rats

Abbreviations:
Adequate nutrition during the prenatal and perinatal periods is of major importance for the proper development of endocrine pathways. An increased risk of adult-onset type 2 diabetes in individuals born with evidence of a disorder in fetal growth suggests that events in early life may have a profound and long-lasting effect on glucose homeostasis (1-4). Indeed, experimental animal models based on prenatal undernutrition

Received April 7, 2000; accepted January 4, 2001.

Correspondence: Patricia Vuguin, M.D., Division of Pediatric Endocrinology, Albert Einstein College of Medicine, Children's Hospital at Montefiore Medical Center, $111 \mathrm{E}$. 210 St., Bronx, NY 10467, U.S.A.

This work was supported by grants from the National Institutes of Health (KO8AG00639 and R29-AG15003), the American Diabetes Association, and by the Core Laboratories of the Albert Einstein Diabetes Research and Training Center (DK 20541). N.B. is a recipient of the Paul Beeson Physician Faculty Scholar in Aging Award. P.V. was a fellow in the division of Pediatric Endocrinology and received support from a fellowship grant from Eli Lilly Research Laboratories.

Presented in part at the 1999 annual meeting of the Society for Pediatric Research, San Francisco, CA, U.S.A. demonstrated the consequences of early insult on the proliferative capacity, size, and vascularization of the islet cell (5). Prenatal undernutrition resulted in a $25 \%$ decrease in pancreatic insulin content and a reduction in pancreatic $\beta$-cell mass to $\sim 40 \%$ compared with the well-fed controls $(6,7)$. An isocaloric low-protein diet given to female rats throughout pregnancy decreased islet size in offspring at birth. When these islets were challenged in vitro with different secretagogues, the insulin response was depressed (8). Similarly, when the low-protein diet was maintained until weaning, there was a $66 \%$ reduction in $\beta$-cell mass that was not fully restored after refeeding at 3 mo of age (9). Furthermore, female rats who suffered prenatal and perinatal malnutrition subsequently manifested an abnormal glucose tolerance test and low insulin levels (10).

In this study, we tested the consequences of moderate caloric restriction throughout puberty. We hypothesized that puberty has an important role in $\beta$-cell maturation and any major 
nutrient modification may have deleterious consequences later in life. To test this hypothesis, we intervened by moderate food deprivation throughout puberty into young adulthood, and tested by clamp techniques the capacity of the $\beta$-cells to respond to different nutrient stimuli.

\section{MATERIAL AND METHODS}

\section{Animals}

Male S-D rats (Charles River Laboratories, Wilmington, MA, U.S.A.), fed AL were used for this study. Pre animals ( $n$ $=14)$ with $\mathrm{BW}<100 \mathrm{~g}$ were studied at $3-4 \mathrm{wk}$ of age. Prepuberty was confirmed by the lack of testicular descent (11). Post rats $(n=8)$ were $\sim 3$ mo old and were identified by testicular descent and balano-preputial separation (11-14). A third group (CR, $n=9)$, was fed AL immediately after weaning until animals reached $\sim 100 \mathrm{~g}$, then they were kept on $\sim 70 \%$ of the diet of the AL-fed rats and studied after puberty at $\sim 3$ mo of age (12). Because food intake changed throughout this period, these animals had a daily adjustment of food intake to match $\sim 70 \%$ of the diet of the AL-fed rats. A steady weight gain was maintained, and puberty was completed later than the AL-fed rats $(\sim 180 \mathrm{~g})(12)$. All rats were fed a standard chow diet that contained $64 \%$ carbohydrate, $30 \%$ protein, and $6 \%$ fat, with a physiologic fuel value of $3.30 \mathrm{kcal} / \mathrm{g}$ chow, and vitamin supplements. The rats were sedentary, housed in individual cages, and subjected to a standard light $(0600-1800 \mathrm{~h}) /$ dark $(1800-0600 \mathrm{~h})$ cycle.

Three to five days before the in vivo study, rats were anesthetized with an i.p. injection of pentobarbital $(50 \mathrm{mg} / \mathrm{kg}$ $\mathrm{BW})$. Indwelling catheters, filled with normal saline and heparin, were inserted in the right internal jugular vein and the left carotid artery. The venous catheter was extended to the level of the right atrium and the arterial catheter was advanced to the level of the aortic arch $(12,15-18)$. Rats were studied when their BW were within $3 \%$ of their preoperative weight.

\section{Body Composition}

LBM and FM were calculated from the whole body volume of distribution of water estimated by tritiated water bolus injection in each experimental rat $(12,15-18)$. On the morning of the study, $20 \mu \mathrm{Ci}$ of ${ }^{3} \mathrm{H}_{2} \mathrm{O}$ (NEN, Boston, MA, U.S.A.) was injected intra-arterially. Steady state for ${ }^{3} \mathrm{H}_{2} \mathrm{O}$-specific activity in rats was generally achieved within $30-45 \mathrm{~min}$, and eight samples were collected between 1 and $1.5 \mathrm{~h}$ after injection. The distribution space of water was calculated by dividing the total radioactivity injected by the steady state-specific activity of plasma water, which was assumed to be $93 \%$ of the total plasma volume. LBM was calculated from the whole body distribution space, divided by 0.73 (the percentage of water content of the LBM). FM was calculated as the difference between total BW and LBM. Epididymal, perinephric, and mesenteric fat pads were dissected and weighed after completion of the study as an additional index of adiposity.

\section{Clamp Studies}

Studies were performed in awake, unstressed, chronically catheterized, 5-6 h postprandial rats $(12,15-19)$. After a 90-min equilibration phase, rats received a variable infusion of $25 \%$ glucose solution at time 0 and were adjusted to clamp the plasma glucose concentration for $90 \mathrm{~min}$ at either $300 \mathrm{mg} / \mathrm{dL}$ or $200 \mathrm{mg} / \mathrm{dL}$ and FFA levels of $\sim 1.5 \mathrm{mM}$ from basal (fasting), respectively. Intralipid was infused as a $20 \%$ emulsion diluted in heparin $1: 3$ at $0.4 \mathrm{~mL} / \mathrm{h} / 100 \mathrm{~g} \mathrm{BW}$ when the plasma glucose was clamped to $200 \mathrm{mg} / \mathrm{dL}$ for $1 \mathrm{~h}$. Bolus glucose was given to raise glucose levels rapidly to $200 \mathrm{mg} / \mathrm{dL}$, and blood was drawn for measurement of insulin and glucose every 2 min for the first $10 \mathrm{~min}$ to achieve a first-phase insulin response. Blood was then drawn every 10 min for glucose, insulin, FFA, and glycerol levels (20). These samples were immediately placed into cold heparin/lithium-coated microfuge tubes and centrifuged. The plasma was frozen in liquid nitrogen and stored at $-20^{\circ} \mathrm{C}$ until analyzed for other components. The total volume of blood withdrawn was $\sim 2.0 \mathrm{~mL}$ per study. To prevent volume depletion and anemia, a solution $(1: 1 \mathrm{vol} / \mathrm{vol})$ of $\sim 2.0 \mathrm{~mL}$ of fresh blood (obtained by heart puncture from a litter mate of the test animal) and heparinized saline $(10 \mathrm{U} / \mathrm{mL})$ was infused. At the end of the clamp, rats were anesthetized (i.v. pentobarbital $60 \mathrm{mg} / \mathrm{kg} \mathrm{BW}$ ), the abdomen was quickly opened, and the whole pancreas was freeze-clamped in situ with aluminum tongs precooled in liquid nitrogen. The time from the injection of the anesthetic until freeze-clamping of the pancreas was less than $1 \mathrm{~min}$. All tissue samples were stored at $-80^{\circ} \mathrm{C}$ for subsequent analysis.

\section{Semiquantification of mRNA}

Although islets occupy $<1 \%$ of the pancreas, expression of islet-specific gene products can be evaluated by a PCR technique. A semiquantitative reverse-transcriptase (RT)-PCR assay, in which a known amount of a competitor was added to each reaction, was used to compare the levels of insulin I mRNA (21). This competitor was prepared by introducing a small internal deletion into the cloned cDNA using a PCRbased mutagenesis procedure (supplied by Dr. Polonsky) (2123). This internal standard could be amplified using the same primers as the experimental cDNA target and was designed to generate a PCR product that could be easily distinguished from the cDNA target because of the smaller size. RNA was isolated from the whole pancreas of individual animals, using the acidic-guanidinium thiocyanate-phenol-chloroform procedure (24). cDNA was prepared using $1 \mu \mathrm{g}$ of total pancreas RNA and 20 pmol oligo (dT) primer (Perkin-Elmer/Cetus, Norwalk, CT, U.S.A.) in a buffer with dNTP, $2 \mathrm{U}$ of Rnasin (Promega, Madison, WI, U.S.A.), and $200 \mathrm{U}$ of Moloney murine leukemia virus RT (GIBCO, Gaithersburg, MD, U.S.A.). PCR was carried out on a $50-\mu \mathrm{L}$ reaction mixture containing $2 \mu \mathrm{L}$ of the above first-strand cDNA and competitor DNA, $5 \mu \mathrm{L}$ of $10 \times$ PCR buffer $\left(\mathrm{Mg}^{2+}\right.$, Boehringer, Indianapolis, IN, U.S.A.), 1 $\mu \mathrm{L}$ of $10 \mathrm{mM}$ dNTP mix, 4 pmol of each primer, and $2.5 \mathrm{U}$ taq DNA polymerase (GIBCO). The sequence of the upstream primer was 5'-TGCCCAGGCTTTTGTCAAACAGCACCTT-3' and the downstream primer was 5'-CTCCAGTGC- 
CAAGGTCTGAA-3'. The conditions for PCR were $94^{\circ} \mathrm{C}$ for $45 \mathrm{~s}, 53^{\circ} \mathrm{C}$ for $45 \mathrm{~s}$, and $72^{\circ} \mathrm{C}$ for 1 min $(22$ cycles) using GeneAmp PCR system 9600 (Perkin-Elmer). The PCR products were separated by electrophoresis in a $2.5 \%$ agarose gel. The expected RT-PCR product is $187 \mathrm{bp}$ in length whereas the competitor is $165 \mathrm{bp}$ in length. Each lane of the autoradiographs was scanned and analyzed densitometrically comparing the changes in intensity between the product and the competitor.

The study protocol was reviewed and approved by the Animal Care and Use Committee of the Albert Einstein College of Medicine.

\section{Analytical Procedures}

Plasma glucose was measured by the glucose oxidase method (Glucose Analyzer II, Beckman Instruments, Inc., Palo Alto, CA, U.S.A.). Plasma insulin levels were determined by RIA using rat insulin standards (Novo, Copenhagen, Denmark) as standard, and PBS containing $0.1 \%$ BSA as assay buffer (25). Plasma $\left({ }^{3} \mathrm{H}\right)$ glucose radioactivity was measured in duplicate in the supernatants of $\mathrm{Ba}\left(\mathrm{OH}^{2}\right)$ and $\mathrm{ZnSO}^{4}$ precipitates the plasma samples before and after evaporation to dryness to eliminate tritiated water. Plasma nonesterified fatty acids concentrations were determined by an enzymatic method with an automated kit according to the manufacturer's specifications (Waco Pure Chemical Industries, Osaka, Japan). Glycerol was determined using the GPO-Trinder reagents for the quantitative enzymatic determination of glycerol in plasma at $540 \mathrm{~nm}$ (Sigma Chemical Co. Diagnostics, St. Louis, MO, U.S.A.).

\section{Calculations}

The significance of group differences was evaluated by the two-sample $t$ test. Pearson correlation coefficients were calculated to determine the linear relationship between variables. All values are presented as means \pm SE. All statistical analyses were performed using SSPS (SPSS, Inc., Chicago, IL, U.S.A.).

\section{RESULTS}

\section{Characteristics of Experimental Rats}

Characteristics of the experimental rats are shown in Table 1. AL-fed (Post) animals increased their weight by $\sim 4$-fold

Table 1. Body composition (A) and biochemical characteristics (B) of $S-D$ rats

\begin{tabular}{lccc}
\hline & Pre $(n=14)$ & Post $(n=8)$ & CR $(n=9)$ \\
\hline (A) & & & \\
BW (g) & $80 \pm 7^{*}$ & $323 \pm 7$ & $205 \pm 6 \dagger$ \\
FM (g) & $1.5 \pm 1.0^{*}$ & $49.0 \pm 6.0$ & $9.2 \pm 3.4^{*}$ \\
LBM (g) & $79 \pm 6^{*}$ & $273 \pm 9$ & $195 \pm 10 \dagger$ \\
Epididymal fat (g) & $0.3 \pm 0.1^{*}$ & $5.2 \pm 0.3$ & $2.5 \pm 0.3 \dagger$ \\
(B) & & & \\
Glucose (mg/dL) & $141 \pm 5$ & $140 \pm 4$ & $147 \pm 4$ \\
Insulin (ng/dL) & $0.9 \pm 0.2$ & $1.3 \pm 0.3$ & $0.7 \pm 0.1$ \\
FFA (mM) & $0.67 \pm 0.07^{*}$ & $1.06 \pm 0.08$ & $0.82 \pm 0.05 \dagger$ \\
Glycerol (mg/dL) & $0.34 \pm 0.01^{*}$ & $0.50 \pm 0.03$ & $0.41 \pm 0.05$ \\
\hline
\end{tabular}

All values expressed as mean \pm SE.

$* p<0.001$ vs. others.

$\dagger p<0.05$ vs. Post. from Pre compared with CR rats $(\sim 2.5$-fold $)$. This increase in weight was associated with a 5 -fold increase in FM and a 2-fold increase in visceral fat in Post compared with CR rats. Caloric restriction resulted in a $\sim 30 \%$ lower LBM compared with Post animals. All groups had similar fasting glucose levels. However, the fasting plasma insulin levels were decreased in Pre and CR animals compared with Post.

\section{Hyperglycemic Clamps}

Response to glucose. During hyperglycemic clamping, mean plasma glucose concentration was rapidly increased by $\sim 160 \mathrm{mg} / \mathrm{dL}$ and maintained at $\sim 300 \mathrm{mg} / \mathrm{dL}$ throughout the study (Fig. 1A, Table $2 A$ ). The first phase of insulin secretion was defined as the integrated AUC for insulin levels obtained between 0 and $20 \mathrm{~min}$. Post rats had an increase of $\sim 3$-fold in the first phase of insulin secretion compared with Pre and CR rats (Fig. 1B). During hyperinsulinemia and hyperglycemia, FFA were suppressed from basal in all groups (Table $2 B$ ). The GIR needed to achieve hyperglycemia were similar in Pre and Post rats $(36 \pm 2$ and $32 \pm 1 \mathrm{mg} / \mathrm{kg} / \mathrm{min}$, respectively). Remarkably, whereas CR and Pre animals had similar plasma insulin levels, CR rats had a higher glucose requirement (GIR $74 \pm 3 \mathrm{mg} / \mathrm{kg} / \mathrm{min}$ ), suggesting that either the insulin action improved and/or these animals had an increase in noninsulin-

A.
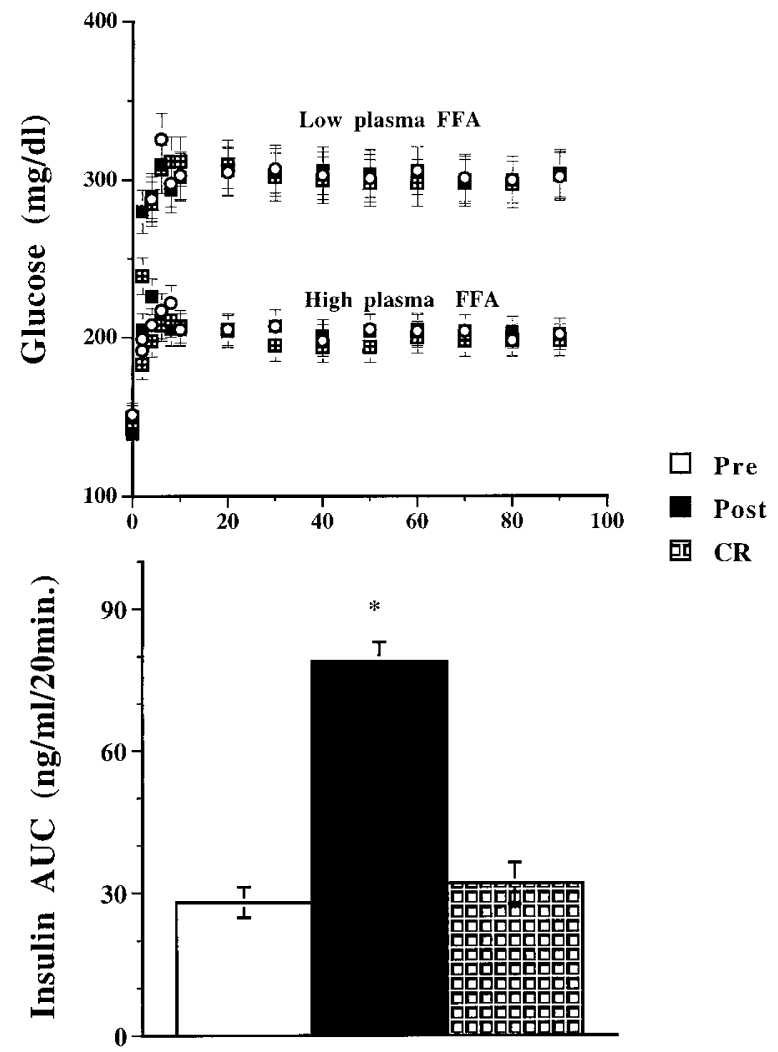

Figure 1. (A) Steady state glucose levels during a hyperglycemic clamp. Glucose levels were maintained at $\sim 300 \mathrm{mg} / \mathrm{dL}$ and FFA levels at $0.5 \mathrm{mM}$ throughout the study (low FFA), or at $200 \mathrm{mg} / \mathrm{dL}$ and FFA $\sim 1.5 \mathrm{mM}$ with an intralipid infusion (high FFA) in Pre, Post, and CR rats. All values are expressed as mean \pm SE. (B) First-phase insulin secretion. AUC for insulin levels obtained between 0 and $20 \mathrm{~min}$ in Pre, Post, and CR rats. All values are expressed as mean $\pm \mathrm{SE}$. 
mediated glucose uptake when compared with Pre rats. During hyperglycemia $(\sim 300 \mathrm{mg} / \mathrm{dL})$, mean plasma insulin concentration increased from $1.2 \pm 0.4 \mathrm{ng} / \mathrm{dL}$ (basal) to $4.6 \pm 0.4 \mathrm{ng} / \mathrm{dL}$ in Pre, from $0.7 \pm 0.1 \mathrm{ng} / \mathrm{dL}$ to $3.8 \pm 0.5 \mathrm{ng} / \mathrm{dL}$ in $\mathrm{CR}$, and from $1.3 \pm 0.3 \mathrm{ng} / \mathrm{dL}$ to $12.8 \pm 0.7 \mathrm{ng} / \mathrm{dL}$ in Post rats $(p<$ 0.001 in Pre and CR versus Post) (Fig. $2 A$, Table $2 A$ ).

Response to $F F A$. During hyperglycemic clamping, mean plasma glucose concentration was increased by $60 \mathrm{mg} / \mathrm{dL}$ maintained at $\sim 200 \mathrm{mg} / \mathrm{dL}$ with an IL infusion of $0.4 \mathrm{~mL} / \mathrm{h} / 100$ g BW throughout the study (Fig. 1A, Table 2B). FFA levels were increased by $70-80 \%$ from basal in all groups. Mean plasma insulin concentration increased from $1.2 \pm 0.4 \mathrm{ng} / \mathrm{dL}$ (basal) to $4.5 \pm 0.4 \mathrm{ng} / \mathrm{dL}$ in Pre rats, from $0.7 \pm 0.1 \mathrm{ng} / \mathrm{dL}$ to $4.6 \pm 0.5 \mathrm{ng} / \mathrm{dL}$ in CR rats, and from $1.2 \pm 0.3 \mathrm{ng} / \mathrm{dL}$ to 15.8 $\pm 0.7 \mathrm{ng} / \mathrm{dL}$ in Post rats ( $p<0.001$ in Pre and CR versus Post) (Fig. 2B, Table 2B). The GIR needed to achieve hyperglycemia were similar in Pre and CR animals $(36 \pm 2,30 \pm 2$, and 26 $\pm 2 \mathrm{mg} / \mathrm{kg} / \mathrm{min}$, in Pre, CR, and Post, respectively). Although we achieved the same FFA levels with the intralipid infusion in all groups, there was only a $\sim 3$-fold increase in insulin levels in Pre and CR compared with Post rats, which sustained a $\sim 13-$ fold increased in insulin secretion (Fig. 2B).

\section{Pancreas and Insulin mRNA Expression}

We measured insulin mRNA I levels by a semiquantitative RT-PCR in stimulated and nonstimulated pancreatic tissue

A.

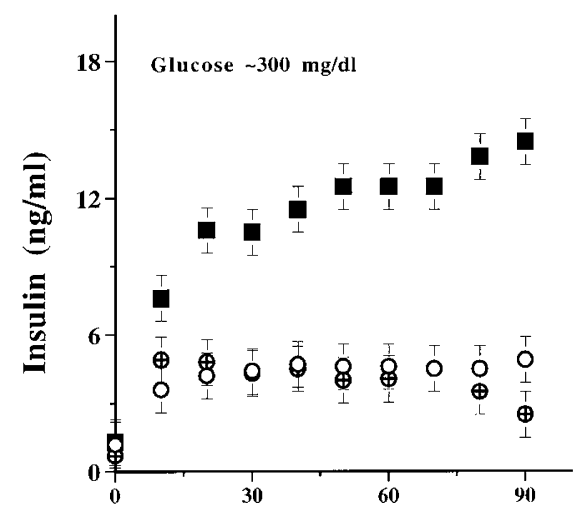

B.

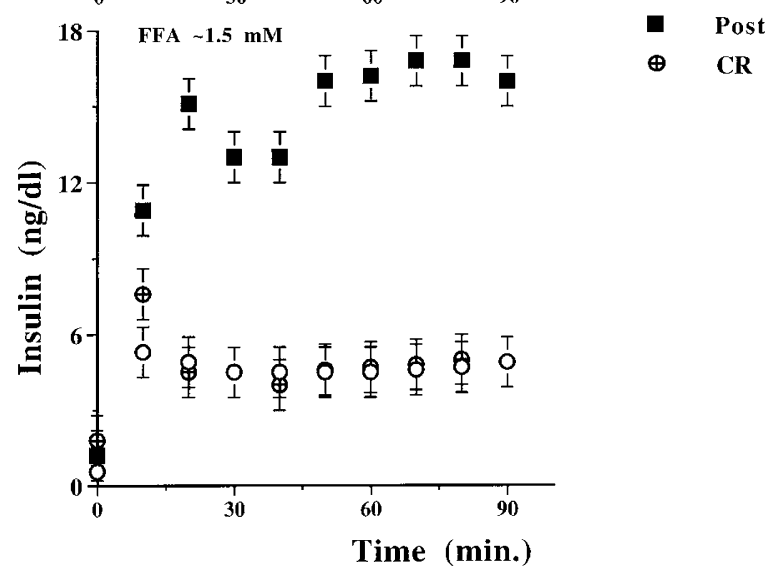

Figure 2. (A) Steady state plasma insulin levels during a hyperglycemic clamp. Glucose levels were maintained at $\sim 300 \mathrm{mg} / \mathrm{dL}$ and FFA at $\sim 0.5 \mathrm{mM}$. (B) Steady state insulin levels during a hyperglycemic clamp. Glucose levels were maintained at $\sim 200 \mathrm{mg} / \mathrm{dL}$ and FFA at $\sim 1.5 \mathrm{mM}$. All values are expressed as mean $\pm \mathrm{SE}$
Table 2. Hyperglycemic clamp (glucose $300 \mathrm{mg} / \mathrm{dL}$ ) (A) Intralipid infusion (glucose $200 \mathrm{mg} / \mathrm{dL}$ ). (B) Change over basal ( $\Delta$ ) for $\frac{\text { plasma glucose, plasma insulin, and FFA in Pre, Post, and CR rats }}{\text { Pre }}$

(A) $\begin{array}{lccc}\Delta \text { Glucose }(\mathrm{mg} / \mathrm{dL}) & 164 \pm 6 & 165 \pm 5 & 158 \pm 6 \\ \Delta \text { Insulin }(\mathrm{ng} / \mathrm{dL}) & 3.4 \pm 0.4^{*} & 11.5 \pm 1.5 & 3.1 \pm 0.5^{*} \\ \Delta \text { FFA }(\mathrm{mM}) & 0.23 \pm 0.2 & 0.32 \pm 0.2 & 0.30 \pm 0.4\end{array}$

(B)

$\begin{array}{lccc}\Delta \text { Glucose }(\mathrm{mg} / \mathrm{dL}) & 60 \pm 6 & 59 \pm 8 & 56 \pm 6 \\ \Delta \text { Insulin }(\mathrm{ng} / \mathrm{dL}) & 3.3 \pm 1.2^{*} & 14.6 \pm 2.0 & 3.9 \pm 0.4^{*} \\ \Delta \text { FFA }(\mathrm{mM}) & 0.46 \pm 0.19 & 0.90 \pm 0.29 & 0.65 \pm 0.39\end{array}$

All values expressed as mean $\pm \mathrm{SE}$.

$* p<0.001$ vs. Post.

(Fig. 3). The abundance of the basal insulin mRNA level in CR rats was $60 \%$ and $80 \%$ that from Post and Pre animals, respectively ( $p=\mathrm{NS}$ ). This probably reflects the size of the pancreas, which decreased by $60 \%$ in CR compared with Post animals $(0.7 \pm 0.1$ versus $1.1 \pm 0.1 \mathrm{~g}, p<0.05$, respectively). Because the stimulated mRNA level can be also assessed by pancreas weight and body size, the response was corrected to reflect the ratio of the pancreas (in grams) to BW (in kilograms).

In $\mathrm{CR}$ rats, the stimulated mRNA level response was no different from Pre rats, whereas it was mildly decreased in Post animals by $\sim 30 \%$ (13.7 \pm 1.0 in Pre versus $13.2 \pm 0.8$ in CR versus $9.1 \pm 0.8$ in Post arbitrary units per $\mathrm{g} / \mathrm{kg} \mathrm{BW}, p<0.05$ Pre and CR versus Post). Although it seems that CR rats had

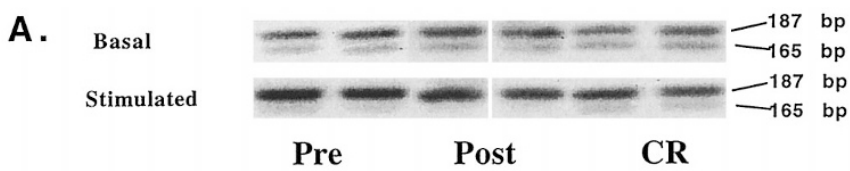

B.

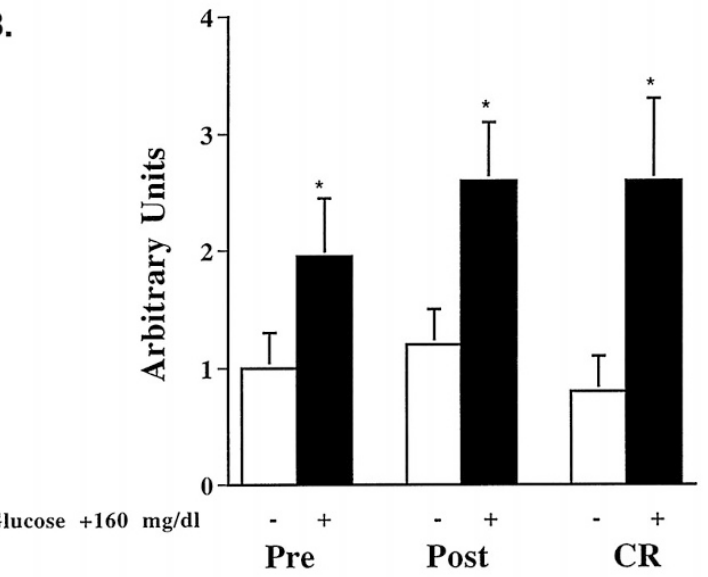

${ }^{*} \mathrm{p}<0.001$ vs. Basal

Figure 3. Semiquantitative RT-PCR showing the abundance of pancreas insulin mRNA I. (A) Nonstimulated (upper lane) and stimulated (lower lane) pancreas tissue. The expected RT-PCR product is $187 \mathrm{bp}$ in length, whereas the competitor is $165 \mathrm{bp}$ in length. $(B)$ Quantitative presentation of $A$. Data are mean \pm SE of mRNA I in arbitrary units in Pre, Post, and CR rats (see "Methods"). 
the most robust response from basal $(\sim 3$-fold), this response did not compensate for the impairment seen in the in vivo insulin secretion.

\section{DISCUSSION}

This study demonstrated a dramatic decrease in insulin secretion in response to near-maximally stimulating secretagogues in adult animals that were moderately nutrient deprived during puberty. This supports the hypothesis that the islet cell's capacity to respond to different stimuli is also determined during puberty and not only during earlier developmental stages.

Insulin secretion is stimulated by a variety of signals, including such nutrients as glucose, FFA, and amino acids. Glucose is a major physiologic stimulus for insulin secretion, and raising glucose levels by $160 \mathrm{mg} / \mathrm{dL}$ over basal (300 $\mathrm{mg} / \mathrm{dL}$ ) is considered maximally stimulating in humans and rodents (26). These stimuli are coupled to glycolysis, changes in the ATP/ADP ratio, depolarization of the membrane, and increases in the calcium flux. The insulin response to maximal glucose stimulation was significantly decreased in CR compared with Post rats, suggesting that these animals have a diminished capacity to respond to a similar stimulus.

FFA are an important physiologic fuel for the islets and act as a supplemental nutrient secretagogue to potentiate insulin release in the presence of glucose. Short-term exposure to intralipid induces insulin secretion in vivo and in vitro (27-29). Recently, it has been postulated that FFA play an important role in signal transduction leading to insulin secretion, either directly or after conversion to malonyl-CoA and long-chain acyl-CoA esters. These molecules may act as metabolic coupling factors in $\beta$-cell signaling (20). Based on studies by Stein et al. $(27,29)$, we designed a protocol that could achieve this response in our animals. Indeed, plasma FFA levels of $\sim 1.5$ $\mathrm{mM}$ (Fig. 2B) resulted in slightly higher insulin levels in Post animals, suggesting that glucose levels of $\sim 300 \mathrm{mg} / \mathrm{dL}$ may not be maximally stimulating for insulin secretion in rats. Interestingly, the insulin response to glucose and FFA was similar in Pre and CR rats. Because CR rats failed to show a similar response to Post animals when stimulated by FFA and glucose, moderately caloric-restricted $\beta$-cells could have a diminished secretory capacity that is not tied to alteration of a specific secretory signal.

Several additional observations suggest that either the development, maturation, or total number of $\beta$-cells is affected in this model. Although the first phase of insulin secretion is dramatically diminished, largely reflecting diminished insulin storage capacity, the magnitude of the stimulated gene expression failed to demonstrate a reason for the impairment of the in vivo insulin response.

Previous studies have demonstrated a decrease in the proliferation, islet cell size, and vascularization of the head of the pancreas in the offspring of mothers fed a low-protein diet during gestation (5). When the same diet was limited to fetal life, the islet cell size was significantly increased and the insulin content was decreased by $12 \%$. On the other hand, when the low-protein diet was maintained after birth, the islet cell size was dramatically decreased $(40 \%)$ at maturity compared with control, and the fasting insulin levels were decreased in the presence of a normal fasting glucose level (8). Even though we did not measure islet numbers or size, the lower mRNA and the decreased pancreas weight found in CR rats may indicate that alterations throughout puberty may impair the $\beta$-cell development and/or maturation. Nevertheless, our studies were largely functional, and the exact anatomy or biology of islet and $\beta$-cell failure with caloric restriction is unclear.

The markedly decreased insulin secretion is not of clinical significance in rat models because the insulin levels achieved are higher than the maximal postmeal insulin levels (1-2 $\mathrm{ng} / \mathrm{mL}$ ). When we analyzed the GIR as a measure of insulin sensitivity, insulin action in Pre and CR rats was improved compared with Post animals $(12,30)$. Thus, insulin levels in Pre and $\mathrm{CR}$ rats are adequate to increase glucose uptake significantly and prevent hyperglycemia. This raises the question of the role of insulin resistance in determining the ability to secrete insulin later in life. The hyperbolic relationship between insulin action and secretion suggests that the decrease in insulin action associated with obesity and aging results in a parallel increase in insulin secretion (31). It is possible that insulin resistance during puberty may also serve as a stimulant for $\beta$-cell maturation. The identities of the specific signals that trigger the compensatory insulin response with insulin resistance are unclear. It may be due to an excess of specific nutrient stimulation (glucose or FFA), underlining the possibility that nutrient deprivation may be the reason for lack of $\beta$-cell development in CR rats.

In this model of caloric restriction, the ability to prevent the development of insulin resistance may result in an irreversible defect in the ability of $\beta$-cells to mature and develop. The advantage of the hyperglycemic technique is that it measures a stimulated insulin response independent of insulin action. To examine whether a chronic insulin resistance stage will salvage the defective insulin secretion, we plan to feed food-deprived animals AL after puberty until the animals reach similar BW to Post rats and to continue these studies into maturity. These experiments appear necessary, as Barker et al. (4) observed type 2 diabetes mellitus in the fifth and sixth decades of life in men and women who suffered impaired fetal growth.

Based on our results, we suggest that puberty has an important role in pancreas maturation and that any major nutritional insult during this developmental stage may have deleterious effects later in life.

Acknowledgments. The authors thank Drs. M. Hawkins and M. Brownlee and Mr. D. Hoffman for critically reviewing this manuscript.

\section{REFERENCES}

1. Phipps K, Barker DJP, Hales CN, Fall CHD, Osmond C, Clark PMS 1993 Fetal and infant growth and impaired glucose tolerance in men and women. Diabetologia 36:225-228

2. Barker DJP, Hales CN, Fall CHD, Osmond C, Phipps K, Clark PMS 1993 Type II (non-insulin dependent) diabetes mellitus, hypertension and hyperlipidemia (syndrome X) relation to reduced fetal growth. Diabetologia 36:65-67 
3. Hales CN, Barker DJP 1992 Type 2 (non-insulin dependent) diabetes mellitus: the thrifty phenotype hypothesis. Diabetologia 35:595-601

4. Hales CN, Barker DJP, Clark PMS, Cox LJ, Fall CHD, Osmond C, Winter PD 199 Fetal and infant growth and impaired glucose at age 64 years. BMJ 303:225-228

5. Snoeck A, Remacle C, Reusens B, Hoet J 1990 Effect of a low protein diet during pregnancy on the fetal rat endocrine pancreas. Biol Neonate 57:107-118

6. Garofano A, Czernichow P, Breant B 1980 Postnatal somatic growth and insulin contents in moderate or severe intrauterine growth retardation in the rat. Biol Neonate 73:89-98

7. Garofano A, Czernichow P, Breant B 1997 In utero undernutrition impairs beta-cell development. Diabetologia 40:1231-1234

8. Dahri S, Snoeck A, Reusens-Billen B, Remacle C, Hoet J 1991 Islet cell function in offspring of mothers on low protein diet during gestation. Diabetes 40:115-120

9. Garofano A, Czernichow P, Breant B 1998 Beta cell mass and proliferation following late fetal and early postnatal malnutrition in the rat. Diabetologia 41:114-1120

10. Garofano A, Czernichow P, Breant B 1999 Effect of ageing on beta-cell mass and function in rats malnourish during the perinatal period. Diabetologia 42:711-718

11. Winter JSD, Faiman C 1990 Control of the onset of puberty. In: Grumbach MM, Sizonenko PC, Acbert ML (eds) Comparative Aspects of Animal and Human Puberty. Williams and Wilkins, Baltimore, pp 211-230

12. Banerjee S, Saenger P, Mitsu H, Chen W, Barzilai N 1997 Fat accretion and the regulation of insulin-mediated glycogen synthesis following puberty in rats. Am J Physiol 273:R1534-R1539

13. Raghavan S, Saenger P, Hu M, Barzilai N 1997 Intracellular pathways of insulin mediated glucose uptake before and after puberty in conscious rats. Pediatr Res 41:340-345

14. Kolho KL, Nikula H, Huhtaniemi I 1988 Sexual maturation of male rats treated postnatally with a gonadotrophin releasing hormone antagonist. J Endocrinol 116:241-246

15. Barzilai N, Rossetti L 1995 The relationship between changes in body composition and insulin responsiveness in models of the aging rat. Am J Physiol 269:E591-E597

16. Barzilai N, She L, Liu BQ, Vuguin P, Wang J, Cohen P, Rossetti L 1999 Surgica removal of visceral fat in rats reverses hepatic insulin resistance. Diabetes 48:94-98

17. Barzilai N, She L, Liu L, Wang J, Hu M, Vuguin P, Rossetti L 1999 Decreased visceral adiposity accounts for leptin's effect on hepatic but not peripheral insulin action. Am J Physiol 277:E291-E298
18. Barzilai N, Banerjee S, Hawkins M, Chen W, Rossetti L 1998 Caloric restriction reverses hepatic insulin resistance in aging rats by decreasing visceral fat. J Clin Invest 101:1353-1361

19. DeFronzo RA, Tobin JD, Andres R 1997 Glucose clamp technique: a method for quantifying insulin secretion and resistance. Am J Physiol 237:E214-E223

20. Rossetti L, Giaccari A, Barzilai N, Howard K, Sebel G, Meizhu H 1993 Mechanism by which hyperglycemia inhibits hepatic glucose production in conscious rats. J Clin Invest 92:1126-1134

21. Siebert PD, Larrick JW 1992 Competitive PCR. Nature 359:557-558

22. Siebert PD, Larrick JW 1993 PCR MIMICS: competitive DNA fragments for use as internal standards in quantitative PCR. Biotechniques 14:244-249

23. Tokuyama Y, Sturis J, DePaoli AM, Takeda J, Stoffel M, Tang J, Sun X, Polonsky KS, Bell GI 1995 Evolution of $\beta$-cell dysfunction in the male Zucker diabetic fatty rat. Diabetes 44:1447-1457

24. Chomczynski P, Sacchi N 1987 Single step method of RNA isolation by acid guanidinium thiocyanate-phenol-chloroform extraction. Ann Biochem 162:156159

25. Herbert V, Lav KS, Gottlieb C, Bleicher S 1965 Coated charcoal immunoassay of insulin. J Clin Endocrinol Metab 25:1375

26. Ashcroft S, Bassett J, Randle P 1972 Insulin secretion mechanisms and glucose metabolism in isolated cells. Diabetes 21(suppl 2):538-545

27. Crespin SR, Greenough WB, Steinberg D 1973 Stimulation of insulin secretion by long chain free fatty acids. J Clin Invest 53:1979-1984

28. Malaisse WJ, Malaisse-Lagae F 1968 Stimulation of insulin secretion by noncarbohydrate metabolites. J Lab Clin Med 72:438-448

29. Stein DT, Esser V, Stevenson B, Lane KE, Whiteside JH, Daniels MB, Chen S, McGarry JD 1996 Essentiality of circulating fatty acids for glucose-stimulated insulin secretion in fasted rats. J Clin Invest 97:2728-2735

30. Prentki M, Tornheim K, Corkey BE 1997 Signal transduction mechanisms in nutrient induced insulin secretion. Diabetologia 40:S32-S41

31. Kahn SE, Prigeon RL, McCullogh DK, Boyko EJ, Bergman RN, Schwartz MW, Neifing JL, Ward WK, Beard JC, Palmer JP 1993 Quantification of the relationship between insulin sensitivity and beta-cell function in human subjects. Evidence for a hypermetabolic function. Diabetes 42:163-172 